УДК 37:929:[378:37.091.12.011.3-051]:37.015.31(045)

DOI:

Ірина Розман, кандидат педагогічних наук, доиент кафедри англійської філології та методики викладання іноземних мов Мукачівського державного університету Ірина Западинська, кандидат педагогічних наук, доцент кафедри іноземної філології та перекладу Вінницький торговельно-економічний інститут Київького національного торговельно-економічного університету

\title{
ПЕДАГОГІЧНА БІОГРАФІСТИКА: ШЛЯХИ РОЗВИТКУ ТВОРЧОГО ПОТЕНЦІАЛУ МАЙБУТНІХ ПЕДАГОГІВ
}

Зосереджено увагу на необхідості розвитку творчого потенціалу майбутніх педагогів на основі педагогічної біографістики. Наголочено, що, використовуючи різноаспектні джерела щодо вивчення біографій відомих і маловідомих особистостей, майбутні педагоги виховують у собі иілеспрямованість, гнучкість, розвивають когнітивні й емоційні співпереживання.

Обтрунтовано потребу в необхідності поетапно, але системно розвивати творчий потенціал майбутніх педагогів, звертаючи увагу на креативність та систематичну мотивацію у творчості.

Закцентовано на значенні особових фондів дослідження персоналій, спогадовій літературі.

Зауважено, що творчі надбання яскравих особистостей, які зуміли не тільки виявити, а й розвити свій потенціал, мають великий вплив на сучасне молоде покоління.

Ключові слова: педагогічна біографістика; творчий потенціал; історичні зміни; креативність; розвиток.

$\operatorname{Jim} .5$.

Iryna Rozman, Ph.D.(Pedagogy), Associate Professor of the English Philology and Methods of Teaching Foreign Languages Department Mukachevo State University Iryna Zapadynska, Ph.D.(Pedagogy), Associate Professor of the Foreign Philology and Translation Department of the

Vinnytsia Institute of Trade and Economics of Kyiv National University of Trade and Economics

\section{PEDAGOGICAL BIOGRAPHICAL STUDIES: \\ WAYS TO DEVELOP THE CREATIVE POTENTIAL OF FUTURE TEACHERS}

The article states that studying the life path of both well-known and little-known personalities of Ukraine will help to educate and develop the above factors. Exploring the source base of pedagogical biographical studies: biographical sources, memoir literature, memoiristics, factual material, personal fund material; material, visual, phonetic, written sources; documentary, narrative, mass, concrete-sociological, historiographic sources, we, first of all, get acquainted with the array of biographical research and form the basic position of pedagogical biographical studies in future teachers, according to which, despite the current level of empirical and scientific-theoretical knowledge of Ukrainian historical and pedagogical science about pedagogical personalities, sources and methods of their study public, educational and scientific challenges require to consider the phenomenon of Biography not only from the angle of studying the life of pedagogical personalities in the past for its actualization in the present, but also to use the potential of biographical studies in the study of well-known modern teachers (which is already partially implemented) and other participants in the educational process.

Pedagogical biographistics motivates the development of creative abilities of students by implementing intersectoral ideas based on the concept of personality, encourages students to use the sources of the State Scientific and pedagogical library of Ukraine named after V. A. Sukhomlynsky, achievements of educational and scientificpedagogical institutions and their divisions. It is extremely important for future teachers to contact and study informative sources of important achievements of a number of creative projects: "outstanding teachers of the world", "innovative teachers in Ukraine", "outstanding teachers of Ukraine and the world", "academicians of the National Academy of Sciences of Ukraine", "anniversaries of the National Academy of Sciences of Ukraine".

It is extremely important to teach applicants to use personal and thematic bibliographic indexes; to monitor the development of bibliography in the fields of sukhomlinistics, Makarenko studies, Russian Studies, other personalized scientific and pedagogical areas, and so on.

So, focusing on the proposed topics for the development of creative abilities at student age, a special role belongs to educational activities, since it continues to act as the leading type of activity for the student, and 
ПЕДАГОГІЧНА БІОГРАФІСТИКА:

\section{ШЛЯХИ РОЗВИТКУ ТВОРЧОГО ПОТЕНЩАЛУ МАЙБУТНІХПЕДАГОГІВ}

therefore the main achievements of the individual are associated with it. The realization of the creative potential of the student, the future teacher, in educational activities will become a productive force only when the internal motives of students coincide with the objective tasks that the teacher sets for them. Therefore, to develop the creative potential inherent in each individual means, first of all, to create pedagogical conditions that will contribute to this process.

Keywords: pedagogical biographical studies; creative potential; historical changes; creativity; development.

П остановка проблеми. Випускник закладу вищої освіти сьогодення має бути озброєний як традиційними, так i інноваційними досягненнями педагогіки. Насамперед необхідно звертати увагу на виховання цілеспрямованості, гнучкості, володіння когнітивними і емоційними співпереживаннями. Сучасний педагог повинен вміти критично мислити, використовувати набуті знання як інструмент для розв'язання життєвих проблем. Проблема виховання, оцінювання та впровадження етичних аспектів для опановування емоціями при розв'язанні нестандартних завдань - важлива функція розвитку творчого потенціалу майбутнього педагога.

Аналіз наукових досліджень. Всебічне осмислення і творче використання у процесі вивчення педагогічних персоналій, зважаючи на контекст наукового дискурсу щодо обгрунтування українськими вченими методологічних засад української історико-педагогічної науки, зокрема педагогічноїбіографістики, досліджувалиО. Адаменко, Г. Бєлан, М. Богуславський, С. Гончаренко, Н. Дічек, Т. Завгородня, І. Стражнікова, О. Сухомлинська та ін.

Мета статті полягас в обгрунтуванні необхідності дослідження шляхів розвитку творчого потенціалу майбутніх педагогів на теоретико-методологічних засадах педагогічної біографістики.

Виклад основного матеріалу. Виміри національної педагогічної біографістики в ракурсі історичних змін та перетворень державнополітичної і соціально-економічної системи, $є$ важливими для інтеграції України в світовий культурно-історичний простір, що виступає стимулом всебічної модернізації освіти. Всі зміни сьогодення так чи так пов'язані $з$ історичними змінами у суспільстві.

Радянська освіта вивчалася багатьма західними країнами саме через значні освітньокультурні зміни. Інститути цього напряму забезпечували високу якість знань своїх студентів. Однією 3 необхідних умов результативної роботи має бути безперервне навчання та перехід на якісно новий рівень на основі демократизації і гуманізації середньої та вищої освіти, підвищення якості освіти та виховання молоді.
На це орієнтують і базові законодавчі нормативні акти (Національна стратегія розвитку освіти України на період до 2021 року (2013), Закон України “Про освіту” (2017), Закон України "Про вищу освіту" (2014), Концепція нової української школи (2016) та ін.), які, визначаючи стратегії і перспективи розвитку національної освіти, акцентують увагу на потребі модернізації й збагачення змісту, методів, форм організації виховання і навчання зростаючої генерації на основі творчого використання ідей і досвіду педагогів, освітян, учених, учених минулого та сучасного [2, 4-5].

Володіння комунікативною культурою, уміння працювати в команді, цілеспрямовано використовувати набуті знання як для самореалізації у професійному й особистісному плані, так і в інтересах суспільства, уміти здобувати й аналізувати інформацію, отриману 3 різних джерел, та доцільно впроваджувати і генерувати нові ідеї з метою вивчення та дослідження інноваційних форм діяльності, завдання сучасного педагога.

Виховати та розвинути у себе зазначені вище риси, допоможе вивчення життєвого шляху як відомих, так і маловідомих особистостей України. Досліджуючи джерельну базу педагогічної біографістики (біографічні джерела, спогадову літературу, мемуаристику, фактографічний матеріал, матеріал особового фонду; речові, зображальні, фонічні, писемні джерела; документальні, оповідні, масові, конкретносоціологічні, історіографічні джерела), ми передусім знайомимось 3 масивом біографічних досліджень та формуємо у майбутніх педагогів базове положення педагогічної біографістики, згідно з яким, зважаючи на сучасний рівень емпіричних і науково-теоретичних знань української історико-педагогічної науки про педагогічні персоналії, джерела і методи їхнього вивчення суспільні, освітні й наукові виклики вимагають розглядати феномен біографії не лише під кутом вивчення життедіяльності педагогічної персоналії в минулому задля iï актуалізації в сьогодення, а і використовувати потенціал біографістики в дослідженні знаних сучасних педагогів (що вже частково реалізується) та інших учасників освітнього процесу $[3,45]$.

Розвивати творчий потенціал майбутніх 


\section{ПЕДАГОГІЧНА БІОГРАФІСТИКА: ШЛЯХИ РОЗВИТКУ ТВОРЧОГО ПОТЕНЦАЛУ МАЙБУТНІХПЕДАГОГІВ}

педагогів доцільно поступово і поетапно, звертаючи увагу на креативність та систематичну мотивацію і на спрямування потреби у творчості, досліджувати біографічні відомості особистостей. Найкращий варіант - вивчати життя, праці, погляди, творчі надбання яскравих особистостей, які зуміли не тільки виявити, а й розвинути свій потенціал, тим самим, залишили своє ім'я у пам'яті свого покоління і нащадків - досліджувати їх життєпис.

Розглядаючи педагогічну біографістику у системі сучасної науки та освіти як один із шляхів розвитку творчого потенціалу, необхідно звернути увагу на теоретичні поняття біографічних вчень, загальнонаукові методи педагогічної біографістики, історико-педагогічні та міждисциплінарні її методи дослідження.

Педагогічна біографістика мотивує розвиток творчих здібностей студентів шляхом реалізації міжгалузевих ідей на базі поняття персоналія, спонукає студентів до використання джерел Державної науково-педагогічної бібліотеки України імені В. Сухомлинського, здобутків освітніх і науково-педагогічних закладів та їхніх підрозділів. Майбутнім педагогам надзвичайно важливо вивчити інформативні джерела здобутків низки творчих проєктів: "Видатні педагоги світу”, “Педагоги-новатори в Україні”, “Видатні педагоги України і світу”, “Академіки НАПН України”, "Ювіляри НАПН України”.

Доцільним убачається вчити здобувачів освіти користуватися персональними і тематичними бібліографічними покажчиками; стежити за розвитком бібліографії в галузях сухомлиністики, макаренкознавства, русовознавства, інших персоніфікованих науково-педагогічних напрямів тощо.

Історіографія проблеми іміджу студента, загальні відомості про джерела дослідження педагогічних персоналій, інтегративний підхід, важливі тенденції нагромадження знань про педагогічні персоналії, які є компонентом концептуального підходу, за яким педагогічна біографістика має охоплювати не тільки життєвий шлях і творчий доробок діяча, а й сукупність різновидових джерельних матеріалів і наукових досліджень. Його доцільність обгрунтовуємо тим, що джерелознавчий та історіографічний компоненти педагогічної біографістики відображають широкий комплекс проблем її дослідницько-інформативного забезпечення також результатів, здобутків і прогалин, надбань учених-біографів [3, 52].

Пошук витоків національної педагогічної біографістики, дослідження педагогічних персоналій та ракурсу методів для становлення педагогічної біографістики, - важливий шлях розвитку творчих здібностей майбутніх педагогів.

Обгрунтованим є у життєвих ситуаціях приклад життедіяльності конкретної особистості. Саме тому застосування методу дослідження особових документів спрямовують зусилля вченого на пошук смислу значень, функцій біографії-життя і дозволяють спростовувати традиційні, поширені в історико-педагогічних дослідженнях факти виведення життєвого успіху, адже життєвий і творчий шляхи кожної персоналії завжди винятковий й унікальний. Він супроводжується не лише цілковитим успіхом, але й “блуканнями” теренами життєвих шляхів, духовними і творчими падіннями, які не применшують вартості реального місця і значення особи в історії країни або свого регіону загалом та педагогічної думка зокрема, а вказують, що позитивний результат життя - це велика і відповідальна праця.

Майбутній педагог, який досліджує педагогічну персоналію, не може вносити власні корективи у ії життєдіяльність до особистісно-феноменологічного аспекту, який переважно рефлексується як “супідрядний”, “причиновий”, тобто такий, що детермінує “головний” діяльнісно-творчий аспект життя, який вливається в річище історикопедагогічної думки і часто / переважно становить основний сенс історико-педагогічного дослідження $[3,112]$.

Міждисциплінарно-інтегративний характер біографічного методу, вплив гуманітарних наук на дослідження та взаємозв'язок біографістики, літературознавства, психології і нагромаджений творчий потенціал зумовлює генезу української історико-педагогічної біографістики.

Розвиток творчого потенціалу майбутніх педагогів обгрунтовує ідею сприйняття людини як самодостатнього цілісного індивіда, який прагне реалізувати свій творчий потенціал та сприяє посилення диференційованого принципу в науці і навчанні.

Модернізація освітньої діяльності в галузі педагогічної біографістики, життя і творчість монументальних фігур педагогічного минулого, “поліфонія" загальної наукової та біографічної і педагогічної термінології, міждисциплінарний характер педагогічної термінологічної системи, процес формування наукових галузевих термінологічних систем й алгоритм створення кодифікатора, розгляд педагогічної персоналії 3 позицій синергетики, сукупність ідей, цінностей та переконань у дослідженні педагогічної біографістики, парадигмальний підхід та 
виокремлення вивчення життєдіяльності педагогічних діячів, інтеграція спільних сутнісних аспектів методологічних підходів - низка тем, які пропонуються для більш детального вивчення педагогічної біографістики [2, 34-36].

Творчий потенціал майбутніх педагогів розкриваєтьсяпід час опрацювання біобібліографічних i довідкових видань, які $\epsilon$ складниками інформативного поля педагогічної науки та допомагають орієнтуватися у масштабності галузевих і міжгалузевих студій. Класифікація історико-педагогічних джерел, наукові, історичні, публіцистичні праці щодо дослідження педагогічних персоналій активізують когнітивне ставлення до вивчення біографій [1].

Особливу увагу необхідно приділити діяльності 3 вивчення народної освіти і національного шкільництва. Здобувачам вищої освіти необхідно наголосити на тому, що не звертаючи увагу на ідеологічні нашарування, українська радянська наука має здобутки у вивченні персоналій відомих педагогів XIX-XX ст.

Органічно й послідовно інтегруючи здобутки радянської історіографії та сучасні освітні й теоретико-методологічні виклики, педагогічна наука досліджує біографічні надбання для того, щоб екстраполювати їх для подальшого вивчення. При цьому залежно від предметного поля та мети дослідження, воно стає можливим і для здобувачів вищої освіти.

Необхідно сконцентрувати увагу студентів на тому, що наукові здобутки і зрушення в розвитку української педагогічної бібліографії i біобібліографії припали на добу Незалежності, позаяк за радянського періоду вони зосереджувалися в російських наукових центрах і тільки епізодично відображали здобутки українських науковців [5].

Різні галузі педагогічної науки мають будуватися на засадах взаємо доповнювання, коли, з одного боку, біографістика апелює до результатів інших наук та оперує поняттєвокатегорійним апаратом загальної педагогіки, історії педагогіки та соціальної, вікової, професійної, порівняльної, інших напрямів і галузей педагогіки. 3 іншого - вона пропонує власні здобутки про життя і творчість педагогічних персоналій, які є корисними для науководослідницьких робіт гуманітаристики.

Висновки та перспективи подальших досліджень. Отже, концентруючи увагу на запропонованих темах для розвитку творчих здібностей студентів, особлива роль належить навчальній діяльності, оскільки вона продовжує виступати для студента провідним видом діяльності, і тому головні досягнення індивіда пов'язані з нею. Реалізація у навчальній діяльності творчого потенціалу студента, майбутнього вчителя, стане продуктивною силою тільки тоді, коли внутрішні спонукання студентів збігатимуться $з$ об'єктивними завданнями, які ставить перед ними викладач, тому розвинути закладений у кожній особистості творчий потенціал - значить, передовсім, створити педагогічні умови, які сприятимуть цьому процесу. Подальшого дослідження вимагає проблема методів вивчення педагогічної біографістики в закладах вищої освіти.

\section{ЛІТЕРАТУРА}

1. Дічек Н. Біографічний метод як інструмент дослідження вітчизняної історії педагогіки. Шлях освіти. 2001. № 4. С. 15-19.

2. Розман I. І. Педагогічна біографістика: навчальний посібник. Ужгород: РІК-У, 2020. С.24-25.

3. Розман I. I. Українська педагогічна біографістика (друга половина XX - початок XXI століття): монографія. Ужгород: РІК-У, 2020. 618 с.

4. Розман I. І. Шляхи вивчення біографії особистості. Proceedings of XXXVIII International Scientific Conference - Science achievements. Morrisville: Lulu Press, 2018. P. 79-81.

5. Савченко С. В. Педагогічний підхід: генеза та сутність поняття. Методологічні засади педагогічного дослідження: монографія. Луганськ, 2003. С. 35-43.

\section{REFERENCES}

1. Dichek, N. (2001). Biohrafichnyi metod yak instrument doslidzhennia vitchyznianoi istorii pedahohiky [Biographical method as a tool for studyingthe national history of pedagogy]. The path of education. No. 4 , pp. 15-19. [in Ukrainian].

2. Rozman, I. I. (2020). Pedahohichna biohrafistyka: navchalnyi posibnyk [Pedagogical biology: a textbook]. Uzhhorod, pp. 24-25. [in Ukrainian].

3. Rozman, I. I. (2020). Ukrayinska pedahohichna biohrafistyka (druha polovyna XX - pochatok XXI stolittya) [Ukrainian pedagogical biography (second half of the XX - beginning of the XXI century)]. Uzhhorod, 618 p. [in Ukrainian].

4. Rozman, I. I. (2018). Shliakhy vyvchennia biohrafii osobystosti [Ways to study the biography of the individual [Ways to study the biography of the individual] Proceedings of XXXVIII International Scientific Conference - Science achievements. Morrisville, pp. 79 81. [in Ukrainian].

5. Savchenko, S. V. (2003). Pedahohichnyi pidkhid: heneza ta sutnist poniattia [Pedagogical approach: genesis and essence of the concept]. Methodological principles of pedagogical research: monograph. Luhansk, pp. 35 43. [in Ukrainian].

Стаття надійшла до редакції 06.08.2021 